interest in, and knowledge of, the wild life of the country (faunal and floral), the customs, history, arts and crafts of its peoples, and sports of all kinds. It publishes a quarterly journal, The Nigerian Field, and it encourages interest in native arts and crafts and in history by awarding prizes for school essays; another object is the institution of a National Museum of Natural History, Ethnography, and History.

The membership fees are (a) $£ \mathrm{I}$ for Fellows, $(b)$ ros. for Members, and (c) ss. for Associates. The latter grade is open to Africans only, but Africans are also eligible for $(a)$ and $(b)$.

The Journal is of a high standard, with excellent illustrations and so varied in its contents that the surprisingly large membership of the Society can be well understood. Some of the subjects dealt with in the July and October numbers, 1938, are: 'The distribution of Negro Sculpture in Southern Nigeria', 'A visit to Old Oyo' (the ancient Yoruba capital, also called Katunga, which was destroyed in I837 by the Fulani), "An Ibo Autobiography' (by Eke Kalu, who was born about I875), native stories, serial articles on antelopes and other animals and on plant life, among them one on some West African shrubs, trees, and vines now growing in the United States. The Nigerian Field is also of importance to anthropologists; it provides information not found elsewhere.

\title{
The Study of African Languages.
}

THE article published under this title in the January number of Africa has been received with great interest. In order to stimulate further investigations the Editor would be grateful if readers would criticize or supplement the statements made in that article, for it is natural that in very many cases only individuals on the spot can give a true picture of the linguistic situation and needs in a district, or they may be able to supply information which is not known outside a narrow circle.

One piece of valuable information of this kind has been contributed by the Rev. A. Prost, Procure des Pères Blancs, Paris, who says that a Dictionnaire Moré (Mossi)-Français and Français-Moré, as well as a very complete Grammar of the same language, was prepared by the Rev. P. Alexandre and published in 1935 by the Maison Carrée in Algiers.

Father Prost has himself compiled a Dictionary of 275 pages of Bisa, the language of the Boussanse, a Mandingo tribe in Mossi country, closely allied to Samo and to Busa. This has not been printed, but typed and duplicated. He is also preparing a Grammar of this language. 